\title{
The necessity of a structured framework for considering pathological lying in the forensic context
}

\author{
Alexia Paraskevoulakou ${ }^{1,2^{*}}$, Vasiliki Antonopoulou ${ }^{1,2}$ \\ From $1^{\text {st }}$ International Congress on Neurobiology and Clinical Psychopharmacology and European \\ Psychiatric Association Conference on Treatment Guidance \\ Thessaloniki, Greece. 19-22 November 2009
}

\section{Background}

Although the psychiatric literature reveals no consensus over the concept of pathological lying, it systematically reflects the significance of this concept in forensic psychiatry. A growing number of case reports underline the implications of untruths in a legal context. This study aims to define these implications.

\section{Materials and methods}

Our bibliographic review of recent case reports strongly suggests that pathological liars share an extraordinary, yet paradoxical profile: individuals beyond suspicion, prominent men with social status (Judge Couwenberg and Professor Joseph Ellis) and women incarnating the graces of motherhood (later on to be diagnosed with Munchausen by Proxy) seeming particularly genuine and convincing, often driven by their lies to a clash with the judicial system or administrative structures (such as hospitals). This review also traces the historical development of pathological lying and its place in modern-day psychiatry.

\section{Results}

Pathological liars progressively merge into an apparent delusional establishment of a fictional self overwhelming the real one, state which is commonly described as a kind of "wish psychosis" in which the mastery of one's own lies is irremediably lost. Their ulterior engagement in criminal behaviour unfailingly underlines the lack of will in the act of lying as an end in itself.

\section{Conclusions}

Modern psychiatry fails to determine to which extent pathological lying reflects impairment in reality testing, therefore can not define pathological lying as a wilful act. Even though pathological lying doesn't reach the threshold of insanity, it should be better placed in the DSM so that a structured framework in forensic context could be established in the future.

\section{Author details}

${ }^{1}$ Department of Psychology, University of Paris VIII, Paris, France. ${ }^{2}$ Hospital of Paidon Agia Sophia, Athens, Greece.

Published: 22 April 2010

doi:10.1186/1744-859X-9-S1-S231

Cite this article as: Paraskevoulakou and Antonopoulou: The necessity of a structured framework for considering pathological lying in the forensic context. Annals of General Psychiatry 2010 9(Suppl 1):S231.
Submit your next manuscript to BioMed Central and take full advantage of:

- Convenient online submission

- Thorough peer review

- No space constraints or color figure charges

- Immediate publication on acceptance

- Inclusion in PubMed, CAS, Scopus and Google Scholar

- Research which is freely available for redistribution

Submit your manuscript at www.biomedcentral.com/submit
C Biomed Central 